\title{
Correction to: The clinical significance of CTC enrichment by GPC3-IML and its genetic analysis in hepatocellular carcinoma
}

\author{
Bin $\mathrm{Yi}^{{ }^{1 \dagger}}$, Tian $\mathrm{Wu}^{2 \dagger}$, Nan Zhu ${ }^{1 \dagger}$, Yao Huang ${ }^{1}$, Xiaoyu Yang ${ }^{1}$, Lei Yuan ${ }^{3}$, Yingjun $\mathrm{Wu}^{3}$, Xiaofei Liang ${ }^{2^{*}}$ and \\ Xiaoqing Jiang ${ }^{3^{*}}$ (D)
}

Correction to: J Nanobiotechnol (2021) 19:74 https://doi.org/10.1186/s12951-021-00818-3

Following publication of the original article [1], the authors identified that there was a problem in Fig. 4 when they reviewed the data of article.

In Fig. 4, the experiment of the Perls Stain in column 7 was not designed at the very beginning of the initial experiments. The aim of Perls Stain experiment is to show iron-containing in GPC3-IML. After the completion of simultaneous experiments of columns 1-6, we supplemented the experiment of Perls Stain by selecting the same cell line and performing at the corresponding time to prove this point. Thus, the image of Perls stain in column 7 is not consistent with the other columns in terms of cell number, magnification and locations, and is with wrong scale bar. Although the images of experiment of column 7 could prove the existence of GPC3IML, the integrity and logic of the whole experiments were compromised. After the manuscript was accepted, we repeated the all experiments involved in each column of Fig. 4 in the same period in order to better express the significance of this study and to be better understood by readers.

The corrected Fig. 4 and the corrected figure caption are given below. The correction of these figures does not affect the results and conclusion. All authors agree to these corrections and apologize for these errors.

The correct Fig. 4 is published in this Correction article, and the original article has been corrected.

Corrected Fig. 4:

(c) The Author(s) 2021. This article is licensed under a Creative Commons Attribution 4.0 International License, which permits use, sharing, adaptation, distribution and reproduction in any medium or format, as long as you give appropriate credit to the original author(s) and the source, provide a link to the Creative Commons licence, and indicate if changes were made. The images or other third party material in this article are included in the article's Creative Commons licence, unless indicated otherwise in a credit line to the material. If material is not included in the article's Creative Commons licence and your intended use is not permitted by statutory regulation or exceeds the permitted use, you will need to obtain permission directly from the copyright holder. To view a copy of this licence, visit http://creativeco mmons.org/licenses/by/4.0/. The Creative Commons Public Domain Dedication waiver (http://creativecommons.org/publicdomain/ zero/1.0/) applies to the data made available in this article, unless otherwise stated in a credit line to the data. 


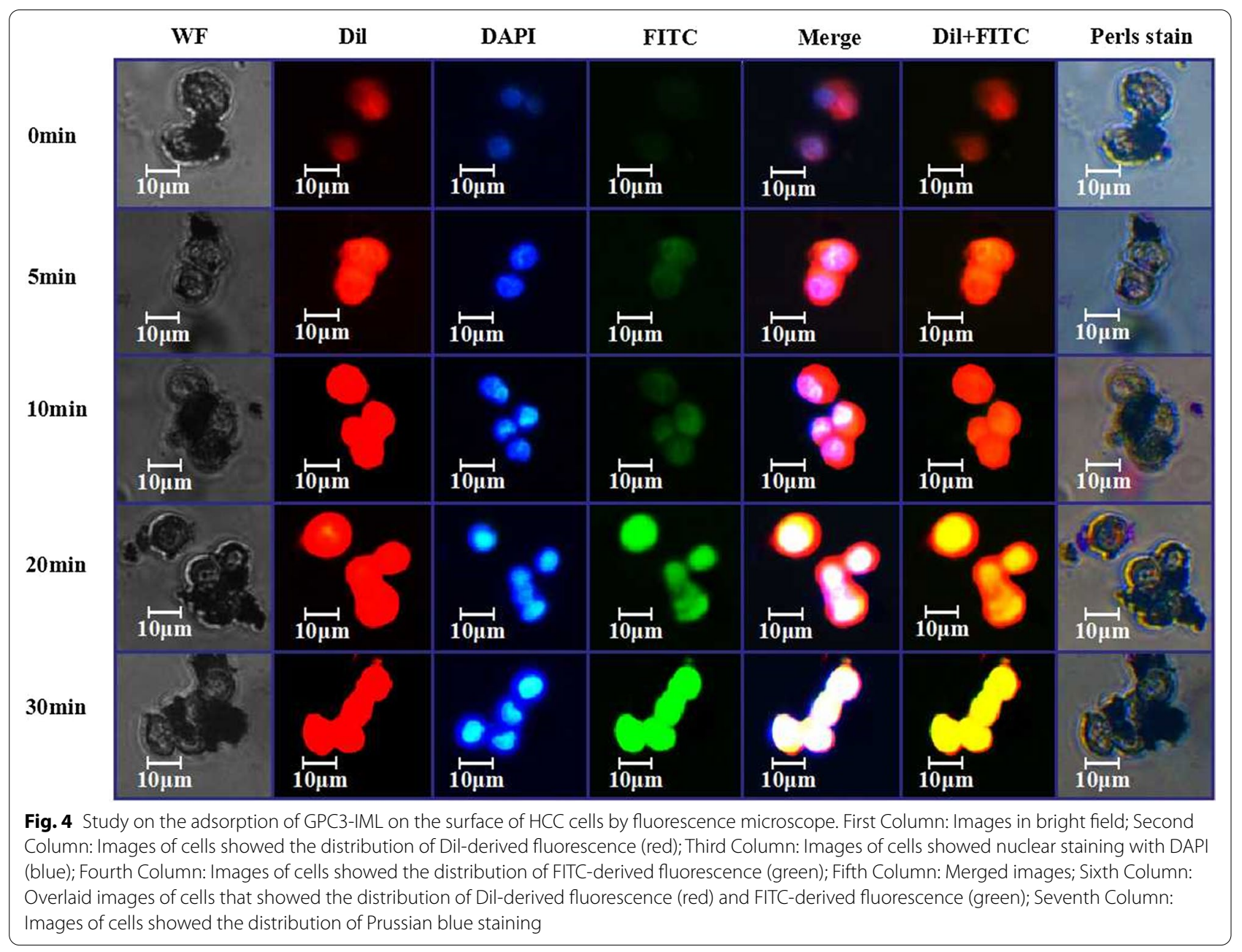

Attached instructions of Experimental Procedure of Perls Staining for GPC3-IML:

(1) $1 \times 10^{4}$ MHCC97-L cells were inoculated and $3 \mathrm{~mL}$ cell culture solution was added in a culture. The cells were cultured at $37^{\circ} \mathrm{C}$ in a $5 \% \mathrm{CO}_{2}$ incubator for $24 \mathrm{~h}$.

(2) After the change of culture solution, $20 \mu \mathrm{L}$ GFAPIML, $100 \mu \mathrm{L}$ DAPI, $100 \mu \mathrm{L}$ Dil and $50 \mu \mathrm{L}$ GFAPFITC were added into per culture plate.

(3) The culture plate was fixed to the microscope and cell images was captured at $0 \mathrm{~min}$.

(4) The culture plate was placed in an incubator at a constant temperature, and the culture solution was drawn from the plate into the Eppendorf tube after 5 min. A very small amount of culture solution was added to take images.
(5) The culture plate was still attached to the microscope and the culture solution was poured from the Eppendorf tube into the culture plate. 5 min later, the culture solution was drawn from the plate into the Eppendorf tube. A very small amount of culture solution was added to take images at $10 \mathrm{~min}$.

(6) The culture solution was poured from the Eppendorf tube into the culture plate and the plate was placed in an incubator at a constant temperature. After $10 \mathrm{~min}$, the culture solution was drawn from the plate into the Eppendorf tube. A very small amount of culture solution was added to take images at $20 \mathrm{~min}$.

(7) The culture plate was still attached to the microscope and the culture solution was poured from the Eppendorf tube into the culture plate. After $10 \mathrm{~min}$, the culture solution was drawn from the plate into 
the Eppendorf tube. A very small amount of culture solution was added to take images at $30 \mathrm{~min}$.

\section{Author details}

${ }^{1}$ Department of Organ Transplantation, Eastern Hepatobiliary Surgery Hospital, Second Military Medical University, Shanghai, China. ${ }^{2}$ Jukang (Shanghai) Biotechnology Co. Ltd, 28, Xiangle Rd, Shanghai 201800, China. ${ }^{3}$ Department of Biliary Tract, Eastern Hepatobiliary Surgery Hospital, Second Military Medical University, No. 225, Changhai Rd, Shanghai 200438, China.

Published online: 12 June 2021

\section{Reference}

1. Yi B, Wu T, Zhu N, Huang Y, Yang X, Yuan L, Wu Y, Liang X, Jiang X. The clinical significance of CTC enrichment by GPC3-IML and its genetic analysis in hepatocellular carcinoma. J Nanobiotechnol. 2021;19(1):74. https://doi. org/10.1186/s12951-021-00818-3.

\section{Publisher's Note}

Springer Nature remains neutral with regard to jurisdictional claims in published maps and institutional affiliations.
Ready to submit your research? Choose BMC and benefit from:

- fast, convenient online submission

- thorough peer review by experienced researchers in your field

- rapid publication on acceptance

- support for research data, including large and complex data types

- gold Open Access which fosters wider collaboration and increased citations

- maximum visibility for your research: over 100M website views per year

At BMC, research is always in progress.

Learn more biomedcentral.com/submissions 